\title{
A Comparative Study on the Theory of 'Soul' In Christianity and the Doctrine Of 'Gandhabba' in Buddhism
}

\section{Rev. Beligalle Dhammajoti ${ }^{1}$}

\section{Abstract}

The whole world speaks of the theory of 'Soul'. It cannot be separated from the human mind and it is deep-rooted. In religion and philosophy, it is considered to be the immaterial, emotional, and spiritual part of a person. Many religions including Christianity have recognized a sort of incorporeal principle of human being and in all other living things. Buddhism, as an atheistic philosophy, does not speak of 'Soul' and it teaches the theory of 'Soullessness'. Buddhism, in explaining life after death, expounds the doctrine of 'gandhabba' which is somewhat an ambiguous and abstruse theory. This paper tries to examine the doctrine of 'gandhabba' as expounded in the fundamental discourses of the Buddha and inspect whether it has somewhat a closer idea to the theory of soul in Christianity. The research method used here depends upon the literature survey. First, the Biblical and other secondary sources have been examined and relevant information is obtained, and then major Buddhist sutras related to the concept of 'gandhabba' were taken into consideration. Finally, doctrinal aspects of the soul theory in Christianity and gandhabba concept in Buddhist tradition have been comparatively examined.

Keywords: Consciousness, 'gandhabba', Soul, Buddhism, Christianity
${ }^{1}$ Department of Pali \& Buddhist Studies, University of Ruhuna, Sri Lanka

beligalledj@gmail.com 


\section{INTRODUCTION}

The concept of 'Soul' is a major teaching of world religions. Now, the whole world speaks of the theory of soul. Man's mind extremely embraced it and it cannot be uprooted from ordinary man's mind and countless explanations pertaining to the theory of soul are found in the field of philosophy and religion. Christianity can be considered to be the basis of the philosophical thought of Western world. It had an excessive influence on the Western concept of soul. Soul is always considered the emotional, immaterial, and spiritual part of a person. Besides the corporeal body of a person, soul is understood as the incorporeal principle of a person.

Buddhism, as an atheistic philosophy, does not speak of 'Soul'. It teaches the theory of 'Soullessness' or the doctrine of 'anatta'. It is one of the three characteristics of the world, the other two are anicca (impermanence) and dukkha (suffering/anguish). Buddhism, in explaining the life after death, expounds the doctrine of 'gandhabba' which is somewhat an ambiguous and abstruse theory. Many articles that appear in the Sinhala newspapers precisely do not come to a decision of what is really meant by the term 'gandhabba'. The term gandhabba is not given a proper translation yet. Therefore, it is timely and appropriate question to be considered in which sense that Buddhism explains the 'No- soul theory', and in which way that Buddhism explains life after death. What is the real meaning of the term gandhabba of the Buddha's teaching? Here, the emphasis is focused on the soul theory explained in Christianity to elucidate the life after death and Buddhist theory of gandhabba to describe the life after death and rebecoming (Re-birth).

\section{LITERATURE REVIEW}

The Epicureans, Platonists, St. Augustine, St. Thomas Aquinas, Rene Descartes, Benedict de Spinoza, Pythagoras and many other Greek philosophers have expressed various thoughts regarding the concept of "Soul". A number of ideas regarding the theory of soul are explained in Encyclopedia Britannica (2010). Dharmasiri (1974) discusses the Western thought pertaining to soul and Buddhist critique of soul, and also tries to explain "No-Soul Theory" taught in Buddhism. Rahula (1978) tries to elucidate the "No-Soul theory" found in Buddhist teachings. Gnanaseeha (1964) explicitly gives a sort of classification of various theories of soul and discusses the nature of soul theories and negates the existence of soul.

The Mahānidānasutta gives a detailed description of the conception of a being. The Culla-kammavibhangasutta explains the nature of kamma and its results. Gnanaseeha (1964) elucidates 
the characteristics of 'Ālaya-viññana' in the light of Buddhist discourses.

Nowhere have we found that there is an approach to compare and contrast the 'Soul Theory' in Christianity with the concept of 'Gandhabba Theory' in Buddhism. The argument of this research paper is that both religions talk of the existence or life after death with their relevant teachings. This can be considered to be a startling new trend to compare a teaching of theistic religion with a doctrine of atheistic religion.

\section{OBJECTIVE OF THE RESEARCH}

The objective of this research work is to explain and understand whether the 'Theory of Soul' in Christianity is closer idea to 'Buddhist theory of Gandhabba' since both systems try to elucidate the same process, that is, the life after death and re-existence.

\section{RESEARCH METHOD}

The research method used here depends on the literary survey. First, the Biblical works and other secondary works have been examined and information has been gathered pertaining to the theory of Soul and then major Buddhist Canonical discourses related to the concepts of 'gandhabba' and "Ālaya-viñ̃nāna" were taken into consideration. In conclusion, these two religious concepts, comparatively, have been examined.

\section{FINDINGS AND DISCUSSION}

'Many cultures have recognized some incorporeal principle of human life or existence corresponding to the soul, and many have attributed souls to all living things of the world. (Encyclopedia Britannica, II,2005:25). The Epicureans considered the soul to be made up of atoms like the rest of the body. St. Augustine argues here: 'And in my disputes with my friends Alypius and Nebridius of the nature of good and evil, I held that Epicurus had in my mind won the palm, had I not believed that after death there remained a life for the soul, and places of requital according to men's deserts, which Epicurus would not believe' (Augustine, 1631: Book vi). Augustine writes: 'But first, wash you, be clean; put away evil from your souls,...' (Augustine, 1631: Book xiii). Here, referring the word 'soul', Augustine may be referring the mental states that are related to evil actions. In Christian Theology St. Augustine spoke of the soul as a "rider" on the body, making clear the split between the material and the immaterial, with the soul representing the true person' (Augustine, 1631). It seems, St. Augustine reflection of 'soul as a rider' equals the idea that mind controls the physical body.

St. Thomas Aquinas explains that soul is the first principle of life and it is equal to mind: 'It is manifest that not every principle of vital action is a soul.....but it is the first principle of life, which we call the soul. .... 
Therefore, the soul, which is the first principle of life, is not a body (Aquinas, 1922: part I, 5). Furthermore, he clarifies: 'We must conclude, therefore, that the human soul, which is called the intellect or the mind, is something incorporeal and subsistent' (Aquinas, 1922: part I, 8).According to ancient Greek philosophers it is an inevitable part of the corporeal body. To Rene Descartes, man was a union of the body and the soul, each a distinct substances acting on the other; the soul was equivalent to the mind. Descartes illustrates: 'These men will be composed, as we are, of a soul, and a body, and I must first separately describe for you the body; then, also separately, the soul; ...' (Descartes, 2003:1). In the Nalakalapasutta of the Samyuttanikāya, the interdependence of mind and matter is clearly explained (Samyuttanikāya II, 1970:114) and it may be compared with the notion of Rene Descartes.

To Benedict de Spinoza body and soul formed two aspects of a single reality. Spinoza explains: '.......nothing can happen in the body which is not perceived by the soul'(Spinoza, 1888: 71). There, he considers that soul is the thinking being. "Pythagoras holds that the soul is of divine origin and exists before and after death (Kardaras, 2011). Epicurus believes that both body and soul ends at death (Samoy: 2019). The early Christian philosophers adopted the Greek concept of the soul's immortality and thought of the soul as being created by
God. They explain 'continuum after death' (Leuba, 2016:82), 'survival after death and immortality (Leuba: 2016: 10) with the concept of God (Leuba, 2016:4). All these philosophical ideas attempt to say that some peculiar hidden thing is there inside the corporeal body of a person. In man, there is an unchanging substance and it is permanent, everlasting and absolute entity is the summery of these ideas.

In Hinduism, the Atman ('breath' or 'soul') is the universal, eternal self, of which each individual soul (jīva or jīva-ātman) partakes. ... At death jìvaàtman passes into a new existence determined by karma, or the cumulative consequences of actions. So, in this way, Hinduism explains the concept of 'A $t m a^{\prime}$ ' in regard to karma formations. It further talks of individual soul and 'Universal Soul' as well. Therefore, the soul as a permanent principle was a favored idea of the ancient Upanisadic philosophy too.

\section{Christianity and the 'Soul Theory'}

In Christian sense, human soul or self is explained as some unobservable, spiritual, and enduring principle or entity. It is, in a way, 'beyond' or 'outside' what is empirically perceptible. In Christianity, the reality of soul is related to the concept of God. According to Jacques Maritain it is considered a permanent principle in man. Dharmasiri quotes Maritain: "A soul which is spiritual in itself, intrinsically independent of matter in 
its nature and existence, cannot cease existing (Dharmasiri, 1974:2). Life after death is explained in Christianity in terms of soul. Life after death is heading to the eternal hell or eternal heaven according to the person's sins and merits. Anyway, it is considered to be an existence after death of a person.

Soul theorists point out that without accepting the existence of a soul there would be no way to explain the facts of personal identity and moral responsibility. Dharmasiri elucidates here: "However, there is the problem of explaining moral responsibility in terms of the no-soul theory" (Dharmasiri, 1974:11). It is true that moral responsibility can easily be clarified with the help of soul theory. The significant point here is that the Christian scholars and soul theorists believe that the idea of the soul is spiritually and morally satisfying and is positively conducive to moral and spiritual progress. Are we entitled to totally neglect the pragmatic results of this concept?

According to Rev. Gnanaseeha, when all the soul theories are taken together, there are threefold division on the concept of soul in Buddhist perspective:

i. Naturally, soul is permanent. It is pervading everywhere like sky. The soul experiences suffering and happiness according to kamma

ii. Soul is permanent. But for long body it is long, for short body it is short. Its nature varies according to the bodies of beings

iii. Soul is permanent. It is subtle. Soul is related to all the functions of body (Gnanaseeha,1964:6)

The undercurrent doctrine of all these theories is continuity or eternal nature of soul, and the moral responsibility totally depends upon the existence of soul. If there is no soul, then who is the doer of actions? Who feels happiness and sufferings for his previous actions? If there is no soul who is going to be reborn? Who are the followers who try to attain Nibbāna? Who are the ones who fulfill perfections in uncountable previous births for attaining the ultimate happiness? These are the questions that are pertaining to the theory of soul, personality, continuity and moral responsibility on the part of soul theorists.

\section{'No-Soul Theory' in Buddhism}

The peculiarity of Buddhism among the world religions is that it denies the existence of 'Soul' or 'Self'. Rev. Rahula explains: 'According to the teaching of the Buddha, the idea of self is an imaginary, false belief which has no corresponding reality, and it produces harmful thoughts of 'me' and 'mine', selfish desire, craving, attachment, hatred, ill-will, conceit, pride, egoism, and other defilements, impurities and problems. It is the source of all the troubles in the world from personal conflicts to wars between nations' (Rahula, 1978: 51). Prof. Dharmasiri adds: 'The Buddha's 
verifiable attitude would strongly reject such an idea because it goes beyond any possibility of knowing the soul's existence (Dharmasiri, 1974:2). In the Mahā-Punnamasutta of the Majjhima-nikāya the Buddha analyses the personality to search whether there is permanent soul in human being, and He questions his disciples:

“Is body permanent or impermanent?

Impermanent, Venerable Sir.

But is what is impermanent nonsatisfying or is it satisfying?

Non-satisfying Venerable Sir.

And is it right to regard that which is impermanent, non-satisfying, liable to change, as 'This is mine, this am I, this is my self'?

No, Venerable Sir"

In this way, the questions were there regarding feelings (vedanā), perception

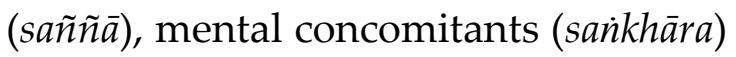
and consciousness (viñ̃āna) (MajjhimaNikaya III, 1977:19). The Buddha explains understanding the 'yathābhūta' (the things as they really are) means knowing the selflessness of the body, feelings, perceptions, mental concomitants, and consciousness.

Mostly, soul theorists are of opinion that mind or the consciousness of mind is the stranglehold of the soul. According to the Buddhist view 'Mind is subject to change so fast, it changes moment by moment'. The Buddha explains: "Monks, I know not of any other single thing so quick to change as the mind: insomuch that is no easy thing to illustrate how quick to change it is" (An̈guttara-Nikāya1, 1961:8). So, mind is constantly changing. In which way, do we apply 'continuous existence' to an entity that rapidly changing?

Why do some persons have such a view on 'soul'? According to Buddhism, it may be strong desire for an immortal life (bhava-tanhāa). It might guide one to believe and find security in the idea of an eternal soul. It is for desire, craving and attachment for the consciousness and its types. According to the Early Buddhist teachings, the theory of 'soul' is a mental projection. Without taking the theory of 'soul' or 'self' the Buddha explains the life after death, moral responsibility and samsāaric life.

The Buddha explains the moral responsibility in accordance with the theory of Causality and Causal continuity. While rejecting the idea of unchanging soul completely, Buddhism explains kamma and its results in terms of a sort of continuity of a person. What really goes from this life to the next life? Many religions explicitly expound that it is 'soul' or 'self' that goes from this life to the next existence. It is very easy and clear-cut answer for many people.

\section{The Theory of 'Gandhabba'}

The Buddhist Canonical term 'gandhabba' has three meanings: a being who presides over child 
conception, musician and a class of celestial beings. (PTS Dictionary, 1993: 244). 'Gandhabba' is a special Pāli term which indicates the connection between the dying person and next life after death. It is used in Buddhist sutras to explain the process of conception without reference to 'soul' or any permanent entity. Therefore, it is the most significant word that is found in Pālisutras to explain the process of 'Punabbhava' or Rebecoming. In accordance with the Mahā-tanhāsainkhayasutta, for conception, there should be simultaneous presence of three things: coitus of parents, mother should be in a proper season (utuni) and the presence of 'gandhabba' (MajjhimaNikāya1, 1979:265-6)

Encyclopedia of Buddhism gives an account quoting the Buddhaghosa's commentary thus: "Buddhaghosa's comment is very clear on the point: "Gandhabba here denotes the being who comes into the scene of conception (tatrupaka-satto); it is not that Gandhabbare mains in the proximity observing the union of the parents; what is implied is that certain being (satto) who is driven on by the mechanism of kamma is about to be born in that situation" (Encyclopedia of Buddhism v,1990:293-4).Here, 'gandhabba' is considered a type of being.

\section{Consciousness Energies}

It seems that Commentator considers 'gandhabba' a sort of being (satto) which does not really, provide the appropriate meaning. Amarakosa's definition for the term 'gandhabba' is given thus: "a being in the intermediate state between death and birth" (Encyclopedia of Buddhism v, 1990: 294). It is said that early nonTheravada Buddhist schools have developed the concept of 'antarāa-bhava' or 'intermediate state of a being' based on the concept of 'gandhabba'. It is more correct to take gandhabba as "Consciousness energies pertaining to any being". Therefore, Buddhism explains the life after death in terms of consciousness energies (Viñ̃ānạashakti).

Gandhabba also means a changeable entity. It is subjected to change, but there is something relating to continuity too. It is endowed with a series of cause-effect generation. Mind and mental concomitants (cetasikas) related to gandhabba get birth and destroyed at the next moment (Gnanaseeha, 1964:12). Therefore, there is a momentary change there. There is no unchangeable soul in the process of gandhabba. So, there is a generation of consciousness which is subject to change but there is a sort of continual connection too. For this, when it is taken in a different way, some thinkers say, 'it is soul'. Therefore, it is suitable to say that gandhabba is a samsāric being in an intermediate state or between death and re-becoming (re-birth) as explained in the Amarakosa (Amarakosa, 1941: 301). The stream of consciousness is the essential entity for 


\section{Original Article}

embryonic development. The Mahanidānasutta emphasizes, if consciousness were not to descent into the mother's womb, or if having descended into the mother's womb were to leave, then conception will not be effective (Digha-Nikāya 11,1982:63).

Therefore, according to the Mahanidannasutta, it is understandable that some entity (gandhabba) come to the mother's womb for conception. That might be the entity or consciousness energies that soul theorists take as the soul. The peculiarity of Buddhist theory is that it never states that gandhabba is a permanent entity, instead it is explained as an entity or energies that which is subjected to change.

\section{The Doctrine of Kamma}

The results of wholesome and unwholesome actions are called 'vipāka'. 'It is always in pregnant meaning of "result, effect, consequence of one's action either as good and meritorious or bad and detrimental' (PTS Dictionary, 1993:627). The person himself is responsible for his actions and is automatically subjected to their results. The Pali formula, "yathāyathāyampurisokammankarotitathā tathātampatisamvedissati" means: "in whichever way this man does a deed, in the same way he will experience it in its effect" (Aniguttara-Nikāya I, 1961:249). "Beingsare owners of kammas, heirs of kammas, they have kammas as their progenitor, kammas as their kin, kammas as their homing place" (Majjhima-Nikāya III, 1977:203). This explicitly shows without any doubt, that the doer of actions would reap the results. But according to the Buddhist theory of impermanence, "Doer is not the same one who reaps the results". In other words, although his consciousness has a continuum state, it is also subjected to the process of momentary change. Therefore, according to Early Theravada Buddhism, we are not entitled to say that there is a continuum state like soul.

\section{The Theory of "Alaya-Viññana"}

If Buddhists are not entitled to say that there is a continuum state like soul, then, what is meant by 'Âlayavinññanna'? The theory of Álaya-

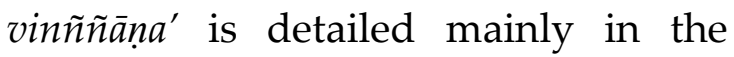
Yogacara Buddhist tradition in India. According to Yogacara tradition, Ālaya-vinñ̃̄āna' means 'Storeconsciousness' or the theory of 'Nondissolution'. The SokaGakkai Dictionary of Buddhism explains: 'Ālaya-vinñ̃nāna' or Ālayaconsciousness' means, storehouseconsciousness, never-perishing consciousness, or maintainingconsciousness (Gakkai: 2002: 11). 'It is called the storehouse consciousness, because all karma created in the present and previous lifetimes is stored there. It is also called the neverperishing consciousness, because the karmic seeds preserved there continue even after death, and the maintainingconsciousness, because it maintains the life and body of a sentient being' 
(Gakkai: 2002:12). According to the quotation of Ekottaragama Sutra taken by Asanga, Álayais here interpreted as 'that which is loved and attached to by living beings'. ...... It was Asanga (4th century A.C.), a great authority of the Yogacara school, who, from the Buddhist standpoint of 'non-self ',proposed for the first time the existence of Álaya-vinññanna which acts as the subject in the cycle of births and deaths (Asanga:2019).

Explaining Ālaya-vinññāna in accordance with the Yogacara Buddhist tradition Chatterjee elucidates: 'It is called Âlaya as it is the place or the receptum in which are contained the seeds or impressions $(v \bar{a} s a n \bar{a})$ of any karma whatsoever, good, bad or indifferent' ...... It is called therefore 'sarva-bijaka', being the cause of everything empirical. It is vipāka because any kind of karma, done by the individual in any sphere of existence, leaves its trace in the Alaya. (Chatterjee,1999:88). Then, who maintain the total cycle of births and rebirths? To elucidate this question Yogacara Idealists takes vipāka-vāsanā related with Âlaya-vinññāna. 'When the repercussions of previous karma come to an end and death intervenes, the activity of vipāka-vāsanā forces the Álaya-viñ̃ñana into a new stream, beginning from the next birth of the individual' (Chatterjee,1999:89).

It is the generating power which gives birth in various living kingdoms in the world systems (Gnanaseeha, 1964:49). The various dhamma-seeds are included in it. It is the consciousness of all seeds (Sarva-bījaka-viñ̃nāna). Ālayavinññanna originates with "seeds of consciousness"- consciousness seeds as its internal part, and "Indriya-shakti" or power of senses as its external part (Gnanaseeha, 1964:59). This Âlayavinññanna' depends on these two and is protected by these two.

A being gets a birth because of the power of consciousness-seeds and the power of senses (Gnanaseeha, 1964:59). Rev. Gnanaseeha (1964) clearly explains: "Ālaya-vinñ̃̃̄ana" every time is undoubtedly endowed with mental concomitants of contact (phassa), attention or fixed thought (manasikāra), feelings (vedanāa),

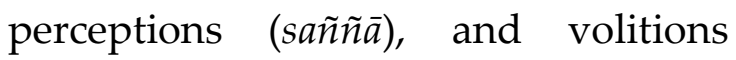

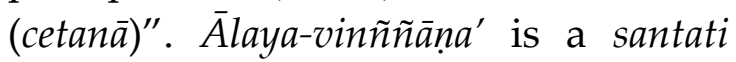
that means 'maturing and continuity' (Gnanaseeha, 1964:69). If it is a santati, then it seems to be a soul-like entity. Álaya-viñ̃̃nāna arises and ceases from moment to moment. From immemorial time, from moment to moment, it exists with the process of arising and ceasing. And it is related to causality, because of that it is not in the nature of eternal entity" (Gnanaseeha, 1964:72).

\section{CONCLUSION}

Christianity explains the life after death in accordance with the soul theory whereas Buddhism expounds the life after death with the doctrinal concepts of 'gandhabba' and 'Älayavinñ $\tilde{n} \bar{a} n a^{\prime}$ by rejecting the soul theory. 
Both religions accept the life after death. In Christianity, the person goes to eternal hell or eternal heaven after the 'Final Judgment Day'. In a way, it means 'the life after death'. Buddhism teaches that the person has a samsāric life or the life of recurrent births and deaths.

By believing the soul entity, Christianity accepts the continuity of a person of this life and the life after death. By expounding the 'Álayaviñ̃̄anna' and gandhabba', Buddhism, although it rejects the concept of soul, explains the continuum of something that is always subjected to change. The peculiarity of Buddhist doctrine is that we are not entitled to say that there is a continuum like soul for it is subjected to momentary change (khanabhamgura). What is suggested here is that the Christian concept of soul should be scrutinized in relation to the philosophical concept of momentary change taught in Buddhist traditions.

Anyway, there should be a continuum for the doer in order to get the results of his previous bad and good deeds. Here, it appears that Älaya-vinñ̃ñanna' or the generating power which gives birth, plays a major role. Theoretically, there is no absolute continuum in the ultimate doctrinal analysis since all the beings are living under the condition of impermanence and especially under the momentary change or the state of khanabhamgura.

\section{References}

Primary Sources:

Asanga. Abhidharmasamuccaya: The Compendium of the Higher Teaching (Philosophy) (trans.) Boin-webb, Sara (2019). New Delhi: Jain Pub. Co.

Añguttara-Nikāya vol. 1. (ed.) Morris, R. (1961). London: Pali Text Society.

Amarakosa of Amarasingha, (ed.) KrishnajiGovind Oka. (1913). Poona: Law PrintingPress.

Dīgha-Nikāyavol. II. (ed.) Rhys Davids, T.W. \& Carpenter, J.E. (1982). London: Pali Text Society.

Majjhima-Nikāya vol. I.(ed.)Trenchner, V. (1979). London: Pali Text Society.

Majjhima- Nikāyavol. II. (ed.) Charmers, R. (1977). London: Pali Text Society.

Majjhima-Nikāyavol. III.(ed.)Chalmers, R. (1977). London: Pali TextSociety.

Samyutta-Nikāya part II. (ed.) Leon Feer, M. (1970). London: Pali Text Society.

Secondary Sources:

Aquinas, St. Thomas. (1922). The Summa Theologica, Part I.(Trans.) Fathers of the English Dominican Province. London: Burns Oates \&Washbourne Ltd.

Augustine, Saint. (1631). St. Augustine's Confessions.London: William Heinemann, (ed.) Page, T.E. and Rouse, W.H.D.,(trans.) Watts,William.

Chatterjee, Ashok Kumar. (1999). The Yogacara Idealism.Delhi:MotilalBanarsidas.

Descartes, Rene. The Passions of the Soul. (trans.) Voss, Stephon. (1989). USA: Hackett Publishing Company, Inc.

Descartes, Rene. Treatise of Man. (trans.) Hall, Thomas Steel. (2003). New York: Prometheus Books.

Dharmasiri, Gunapala. (1074).A Buddhist Critique of the Christian Concept of God. Colombo: Lake House Investment Ltd.

Encyclopaedia of Buddhism, vol. v. (ed.) Weeraratne, W.G. (1990). Colombo: Government of Sri Lanka. 


\section{Original Article}

Gakkai, Soka. (2002). The SokaGakkai Dictionary of Buddhism. Tokyo: SokaGakkai

Gnanaseeha, H. (1964).Vignaptimātratāsiddhivādaya. Colombo: Gunasena\& company.

Kardaras, Nicholas. (2011). How Plato and Pythagoras can save your life, The ancient Greece Prescription for health \& Happiness. USA: Conari Press.

Leuba, James H.. (1916). The Belief in God and Immortality, A Psychological, anthropological and Statistical Study.Boston: Sherman, French \& Company.

Maritain, Jacques. (1953).The Range of Reason. London: Geoffrey Bles.

Rahula, W. (1978). What the Buddha Taught. London:Gordon Fraser Gallery Ltd.

Rhys Davids, T.W. \&Stede, W. (1993). PaliEnglish Dictionary. Delhi: Motilal Banarsidass.

Samoy, S.C. (ed.) (2019). The Philosophy of Epicurus. USA: Dover Thrift Editions.

Spinoza, Benedict De. The Ethics. (trans.) Englewood, N.J. (1888). New York: D. Van Nostrand. 